\title{
$\mathrm{DNA}$ 바코드 분석을 통한 패장 기원종 감별용 분자 마커 개발
}

\author{
김욱진, 지윤의, 이영미, 강영민, 최고야, 김호경, 문병철,** \\ 한국한의학연구원 한약자원그룹

\section{Development of Molecular Marker for the authentication of Patriniae Radix by the analysis of DNA barcodes.}

\author{
Wook Jin Kim, Yunui Ji, Young Mi Lee, Young Min Kang \\ Goya Choi, Ho Kyoung Kim, Byeong Cheol Moon",*
}

Herbal Medicine Resources Group, Korea Institute of Oriental Medicine, Daejeon, 305-811, Republic of Korea

\begin{abstract}
Objectives : Due to the morphological similarity of in the roots of herbal medicine, the official herbal medicine is very difficult to authenticate between the original plants of Patriniae Radix and two adulterant Patrinia species. Therefore, we introduced DNA barcode analysis to establish a powerful tool for the authentication of Patriniae Radix from its adulterants.

Methods : To analyze DNA barcode regions, genomic DNA was extracted from twenty-nine specimens of Patrinia scabiosaefolia, Patrinia villosa, Patrinia saniculifolia, and Patrinia rupestris, and internal transcribed spacer 2(ITS2), matK and rbcL genes were amplified. For identification of species specific sequences, a comparative analysis was performed by the ClastalW based on entire sequences of ITS2, matK and rbcL genes, respectively. Results : In comparison of three DNA barcode sequences, we identified 22, 22, and 12 species-specific nucleotides enough to distinguish each four species from ITS2, matK and rbcL gene, respectively. The sequence differences at the corresponding positions were available genetic marker nucleotides to discriminate the correct species among analyzed four species. These results indicated that comparative analysis of ITS2, matK and rbcL genes were useful genetic markers to authenticate Patriniae Radix.

Conclusions : The marker nucleotides enough to distinguish $P$. scabiosaefolia, $P$. villosa, $P$. saniculifolia, and $P$. rupestris, were obtained at $22 \mathrm{SNP}$ marker nucleotides from ITS2 and matK DNA barcode sequences, but they were confirmed at 12 SNP marker nucleotides from rbcL. These differences could be used to authenticate Patriniae Radix from its adulterants as well as discriminating each four species.
\end{abstract}

Key words : DNA barcode, Patriniae Radix, internal transcribed spacer 2 (ITS2), matK gene, rbcL gene, molecular authentication

\section{서 론}

한의학에서 패장은 성미가 寒苦辛하여, 소종배농(消腫排 膿), 청열해독(淸熱解毒)의 효능으로 패옹(肺痕), 폐농양(肺膿 瘍), 간농양(肝膿瘍), 자궁내막염(子宮內膜炎), 자궁부속기염 (子宮附屬器炎), 난소낭종(卵巢囊腫) 등의 염증성 질환에 양호 한 치료효과가 있는 것으로 알려져 있다 ${ }^{1)}$. 우리나라에 자생하
고 있는 같은 과(Family)의 동속(Genus) 식물로는 돌마타리 (Patrinia rupestirs)와 금마타리(Patrinia saniculifolia)가 자생하고 있으며, 예부터 마타리과 식물의 뿌리, 잎은 정신병 질환, 신경쇠약증, 불면증, 진정 등을 치료하는 민간약으로 이용되었다 ${ }^{2)}$. 패장(敗醬)은 대한민국약전외 한약(생약)규격집에 마타리과(Valerianaceae)의 뚝갈 Patrinia villosa Jussieu 또는 마타리 Patrinia scabiosaefolia Fischer ex Link의 뿌

\footnotetext{
*\#\#Correspondence and First Author. Byeong Cheol Moon. Herbal Medicine Resources Group, Korea Institute of Oriental Medicine, 1672 Yuseong-daero, Yuseong-gu, Daejeon 305-811, Republic of Korea.

- Tel : +82-42-868-9530 · FAX : +82-42-868-9541 · E-mail : bcmoon@kiom.re.kr

- Received : 13 October 2014 - Revised : 10 November 2014 - Accepted : 11 November 2014
} 
리로 그 기원을 규정하고 있으며 ${ }^{3)}$, 중화인민공화국약전 부록 에서는 마타리와 뚝갈의 전초를 패장초로 규정하고 있다 ${ }^{3)}$. 하 지만 패장은 황화패장과 백화패장으로 구분되어 황화패장인 마타리는 급성췌장염 억제효과, 궤양성 대장염 억제효과, 골 수암 세포주에서 항암효과 등이 알려져 있고 백화패장인 뚝갈 은 항염효과, 정유성분의 항산화효과, 항암효과 등이 알려져 있어 각각은 염증억제에 대한 효능이 주류를 이루고 있음을 알 수 있으나 세부적인 효능을 비교하면 차이를 보인다 ${ }^{4)}$. 따 라서 황화패장과 백화패장의 개별 효능은 보다 상세한 비교 · 분석을 통해 구체적인 효능의 차이를 검토할 필요가 있으며, 약재 상태에서의 황화패장과 백화패장의 정확한 구별과 더불 어 혼 - 오용 가능성이 높은 같은 속의 돌마타리나 금마타리와 의 구별이 필요한 실정이다.

최근 분자생물학의 발전과 염기서열 분석기술의 발달로 유 전자 분석을 통한 식물 분류 연구가 활발하게 진행되고 있으며, 국제생물바코드 컨소시엄(CBOL, Consortium of Barcoding of Life)에서 식물의 특정 유전자 부위의 염기서열정보로 이 루어진 DNA 바코드를 이용하여 종의 판별 및 분자계통학적 연구가 가능한 것을 보고하고 있닫). DNA 바코드로 이용되는 대표적인 유전자 부위로 핵의 리보솜 RNA 유전자(Nuclear Ribosomal RNA gene, rDNA)에 존재하는 internal transcribed spacer(ITS) 부위, matK, $r b c \mathrm{~L}, p s b \mathrm{~A}-\operatorname{trnH}$ 유전자 등이 식물 종 판별을 위한 유전자 후보로 제시하고 있으며, 이들 유전자를 이용한 객관적인 식물 분류체계 확립 및 종간 유연 관계 분석을 위한 분자계통학적 연구가 활발히 진행되고 있다 6,7) 특히 게놈상에 존재하는 ITS 부위는 다른 유전자의 코딩 부위보다 빠르게 진화하고 일반성, 단순성, 재현성 등의 이점 으로 인해 계통분류나 종간 유전변이 탐색 등을 위해 이용되 는 염기서열로 알려져 있다 ${ }^{8)}$. 또한, matK 및 $r b c \mathrm{~L}$ 유전자 부위는 대부분의 식물 종에서 잘 보존되어있는 염기서열로 $\mathrm{CBOL}$ 에서 식물 $\mathrm{DNA}$ 바코드 후보로 활발하게 연구를 진행 하여 $\mathrm{DB}$ 화 하고 있다 ${ }^{9,10)}$. 이러한 $\mathrm{DNA}$ 바코드 분석기술은 혼·오용 한약재인 반하 ${ }^{11)}$, 천궁 ${ }^{12)}$, 시호 ${ }^{13)}$, 오미자 ${ }^{14)}$ 등의 다양하게 품목의 적용되어 한약재의 객관적 감별법 개발에 응 용되고 있다.

본 연구에서는 황화패장인 마타리와 백화패장인 뚝갈, 그 리고 이들과 뿌리와 약재 가공시 형태가 유사하여 혼 - 오용될 가능성이 있는 돌마타리와 금마타리를 국내·외 다양한 자생 지에서 수집하여 대표적으로 이용되고 있는 DNA 바코드 부 위인 ITS2, matK, rbcL 유전자의 염기서열 정보 분석을 통해 종 단위에서 명확하게 감별할 수 있는 DNA marker nucleotide 를 발굴하고 분자마커를 개발하여 패장의 구별과 혼 - 오용 방 지를 위한 감별법으로 활용하고자 하였다.

\section{재료 및 방법}

\section{1. 실험 재료}

본 실험에 이용된 기원식물 시료는 경상도, 전라도, 충청도 등의 각각 다른 국내 자생지에서 수집하였고 국외의 경우 중 국 길림성 연길시, 화룡시, 장백현 등지의 다른 자생지와 재 배지에서 수집하여 마타리 8 개, 뚝갈 5 개, 돌마타리 4 개, 그
리고 금마타리 12 개의 시료를 분석에 이용하였다(Table 1). 수집한 시료는 본초학, 생약학, 식물분류학 등의 전문가로 구 성된 분류-동정 자문회의 동정을 거쳐 그 종을 최종 확정지 어 사용하였으며, 각 시료의 기원식물은 압착 표본을 제작하 여 한국한의학연구원 한약표준표본관(KHSHR)에 표본번호를 부여하여 보관하였다.

Table 1. List and Information of Plant Materials Used in This Study.

\begin{tabular}{|c|c|c|c|}
\hline \multicolumn{2}{|c|}{ Name } & \multirow{2}{*}{ Source } & \multirow{2}{*}{$\begin{array}{l}\text { Sample } \\
\text { Name }\end{array}$} \\
\hline Scientific plant & Herbal medicine & & \\
\hline \multirow{8}{*}{$\begin{array}{c}\text { Patrinia } \\
\text { scabiosaefolia } \\
\text { Fischer ex Link }\end{array}$} & \multirow{8}{*}{$\begin{array}{c}\text { Patriniae Radix } \\
\text { (BaiJiang, } \\
\text { PaeJang) }\end{array}$} & Jangsu, Jeonbuk, Korea & JS \\
\hline & & Cheonan, Chungnam, Korea & $\mathrm{CA}$ \\
\hline & & Gapyeong, Gyeonggi, Korea & GP \\
\hline & & Geochang, Gyeongnam, Korea & GC \\
\hline & & Yeongdong, Chungbuk, Korea & $\mathrm{YD}$ \\
\hline & & Gangneung, Gangwon, Korea & $\mathrm{KR}$ \\
\hline & & Yanji, Jilin, China & Cn_YK \\
\hline & & Wangqing, Jilin, China & Cn_WC \\
\hline \multirow{5}{*}{$\begin{array}{l}\text { Patrinia villosa } \\
\text { Jussieu }\end{array}$} & \multirow{5}{*}{$\begin{array}{l}\text { Patriniae Radix } \\
\text { (BaiJiang, } \\
\text { PaeJang) }\end{array}$} & Jangsu, Jeonbuk, Korea & JS \\
\hline & & Cheonan, Chungnam, Korea & $\mathrm{MC}$ \\
\hline & & Gapyeong, Gyeonggi, Korea & GP \\
\hline & & Yeongdong, Chungnam, Korea & $\mathrm{YD}$ \\
\hline & & Gangneung, Gangwon, Korea & $\mathrm{HY}$ \\
\hline \multirow{4}{*}{$\begin{array}{c}\text { Patrinia } \\
\text { rupestris (Pall.) } \\
\text { Juss. }\end{array}$} & \multirow{4}{*}{$-{ }^{\dagger}$} & Yanji, Jilin, China & Cn_YK \\
\hline & & Helong, Jilin, China & $\mathrm{Cn} \_\mathrm{HR}$ \\
\hline & & Changbai, Jilin, China & $\mathrm{Cn} \_\mathrm{JB}$ \\
\hline & & Wangqing, Jilin, China & $\mathrm{Cn} \_\mathrm{WC}$ \\
\hline \multirow{12}{*}{$\begin{array}{l}\text { Patrinia } \\
\text { saniculifolia } \\
\text { Hemsl. }\end{array}$} & \multirow{12}{*}{$-{ }^{\dagger}$} & Pyeongchang, Gangwon, Korea & PC\#1 \\
\hline & & Pyeongchang, Gangwon, Korea & PC\#2 \\
\hline & & Seongju, Gyeongbuk, Korea & SJ\#1 \\
\hline & & Seongju, Gyeongbuk, Korea & SJ\#2 \\
\hline & & Seongju, Gyeongbuk, Korea & SJH3 \\
\hline & & Seongju, Gyeongbuk, Korea & SJ\#4 \\
\hline & & Seongju, Gyeongbuk, Korea & SJ\#5 \\
\hline & & Gapyeong, Gyeonggi, Korea & GP\#1 \\
\hline & & Gapyeong, Gyeonggi, Korea & GP\#2 \\
\hline & & Gapyeong, Gyeonggi, Korea & GP\#3 \\
\hline & & Gapyeong, Gyeonggi, Korea & GP\#4 \\
\hline & & Gapyeong, Gyeonggi, Korea & GP\#5 \\
\hline
\end{tabular}

${ }^{\dagger}$ There is no appropriated name.

\section{DNA 추출}

$-70^{\circ} \mathrm{C}$ 의 초저온 냉동고에 보관된 국내 - 외 자생지 또는 재배지에서 수집한 기원식물 생체시료는 액체질소로 급냉 시 켜 막자와 사발을 이용하여 분말상태로 마쇄한 후, DNasey Plant Mini Kit(QIAGEN, CA, USA)을 이용하여 DNA를 추출. 정제하였다. 정제된 $\mathrm{DNA}$ 는 $1.5 \%$ agarose gel 상에 전기영동 후, Ethidium Bromide(EtBr)로 염색하여 UV light 에서 DNA 절편을 확인하였으며, UV spectrophotometer (Nanodrop ND-1000, DE, USA)를 이용하여 $260 \mathrm{~nm}$ 와 $280 \mathrm{~nm}$ 에서 흡광도를 측정하여 정량 하였다.

\section{DNA 바코드 부위 PCR 증폭 및 염기서열 분석}

약 $20 \mathrm{ng}$ 의 total $\mathrm{DNA}$ 를 주형으로 각 $10 \mathrm{pmole}$ 의 정방 향, 역방향 primer(Table 2) 및 $2 \times \mathrm{PCR}$ pre-mix(Solgent, 
Daejeon, Korea)를 최종 $30 \mu$ 의 반응용액에 첨가하여, DNA Engine Dyad Thermal Cycler(Bio-rad, CA, USA)에서 9 $5{ }^{\circ} \mathrm{C}$ 에서 5 분간 predenaturation 한 후, $95^{\circ} \mathrm{C}$ 에서 30 초 denaturation, $55^{\circ} \mathrm{C}$ 에서 30 초 annealing, $72^{\circ} \mathrm{C}$ 에서 1 분 extention을 35 회 수행하고 $72^{\circ} \mathrm{C}$ 에서 10 분간 extention 시 켰다. 반응이 끝난 증폭산물은 $1.5 \%$ agarose gel 상에서 증 폭 여부를 확인하였고 단일 DNA 절편으로 확인된 증폭산물 은 Gel extraction kit(QIAGEN, CA, USA)을 이용하여 정 제 후 pGEM-Teasy vector(Promega, WI, USA)에 삽입하 였다. 삽입된 증폭 산물은 XL1-Blue MRF' competent cell (Stratagene, $\mathrm{CA}, \mathrm{USA}$ )에 형질 전환하여 각 시료별 3 개의 colony를 선발하였으며 T7과 SP6 primer 부위로부터 ABI3730 automatic DNA sequencer(Applied Biosystems, CA, USA) 를 이용하여 분석된 염기서열을 시료의 표준 염기서열로 선정 하여 DNA 바코드 분석에 이용하였다.

\section{4. 종 판별용 marker nucleotide 발굴}

최종 확증된 각 시료별 29 개체의 $\mathrm{ITS} 2, \mathrm{matK}, \mathrm{rbcL}$ 유전자 염기서열을 DNA 바코드 종류별로 BioEdit program(Version 7.0.9, Tom Hall Ibis Biosciences, CA, USA)의 ClustalW 방법으로 multiple alignment를 수행하여 종내 개체 및 종 별 염기서열을 정렬하였다 ${ }^{15)}$. 정렬된 $\mathrm{ITS} 2, \operatorname{matK}$ 및 $\mathrm{rbcL}$ 염기서열의 종내 개체별 비교와 종별 비교를 통해 종 특이성 을 갖는 염기의 삽입(insertion), 결실(deletion) 및 치환 (substitution)을 위치별로 분석하여 정리하였다(Table 2).

Table 2. The Gene and Primer Sequence Information of DNA Barcodes Used in This Study.

\begin{tabular}{|c|c|c|c|c|}
\hline gene & $\begin{array}{l}\text { primer } \\
\text { name }\end{array}$ & Sequence $\left(5^{\prime} \rightarrow 3^{\prime}\right)$ & $\begin{array}{l}\text { annealing } \\
\text { temperature }\end{array}$ & reference \\
\hline \multirow{2}{*}{ ITS2 } & ITS2-S2F & ATGCGATACTTGGTGTGAAT & \multirow{2}{*}{$55^{\circ} \mathrm{C}$} & \multirow{2}{*}{$\begin{array}{l}\text { White et al. }{ }^{16)} \\
\text { Chen et al. }\end{array}$} \\
\hline & ITS4 & TCCTCOGCTTATTGATATGC & & \\
\hline \multirow{2}{*}{ matK } & matK-AF & CTATATCCACTTATCTTTCAGGAGT & \multirow{2}{*}{$55^{\circ} \mathrm{C}$} & \multirow{2}{*}{ Kato et al. ${ }^{18)}$} \\
\hline & matK-8R & AAAGTTCTAGCACAAGAAAGTCGA & & \\
\hline \multirow{2}{*}{$r b c \mathrm{~L}$} & $r b c L-F$ & ATGTCACCACAAACAGAAACTAAAGC & \multirow{2}{*}{$55^{\circ} \mathrm{C}$} & \multirow{2}{*}{ Mansion et al. ${ }^{19)}$} \\
\hline & $r b c \mathrm{~L}-\mathrm{R}$ & TCCTTTTAGTAAAAGATTGGGCCGAG & & \\
\hline
\end{tabular}

\section{결 과}

\section{DNA 바코드 부위 증폭 및 염기서열 분석}

패장의 감별을 위하여 4 종 29 개의 시료로부터 추출한 게놈 유전자를 주형으로 $\mathrm{ITS} 2, m a t \mathrm{~K} r b c \mathrm{~L}$ 유전자 부위를 $\mathrm{PCR}$ 증폭하여 전기영동으로 확인한 결과, 4 종 29 개 시료에서 모
두 단일 $\mathrm{DNA}$ 절편이 증폭되었고 ITS2 유전자 부위는 약 $400 \mathrm{bp}, \operatorname{matK}$ 유전자 부위는 약 $1,250 \mathrm{bp}$, 그리고 $r b c \mathrm{~L}$ 유 전자부위는 약 $1,450 \mathrm{bp}$ 크기의 DNA 증폭산물을 확보하여 이를 각 시료의 ITS2, matK 및 $r b c \mathrm{~L}$ 바코드 부위로 정의하 였다. 각 시료로부터 얻은 $\mathrm{DNA}$ 바코드 $\mathrm{PCR}$ 증폭산물을 pGEM-Teasy vector (Promega, USA)에 삽입한 뒤, 각 시 료별로 3 개 이상의 Plasmid DNA를 추출하여 삽입된 증폭산 물의 염기서열을 해석하고 이들을 비교하여 각 시료의 최종 유전자 염기서열로 확정하였다. 확정된 각 시료의 유전자 염 기서열을 분석한 결과, ITS2 부위는 뚝갈, 마타리 및 돌마타 리는 $389 \mathrm{p}$ 의 염기로 구성되어 있었고 금마타리는 $392 \mathrm{bp}$ 의 염기로 구성되어있었으며, matK 부위는 뚝갈은 $1,261 \mathrm{bp}$ 의 염기로 마타리, 돌마타리 및 금마타리는 $1,262 \mathrm{bp}$ 의 염기로 구성되어 있었으며, $r b c \mathrm{~L}$ 부위는 4 종 모두 $1,497 \mathrm{bp}$ 의 염기로 구성되어 있었다(Fig. 1-2)

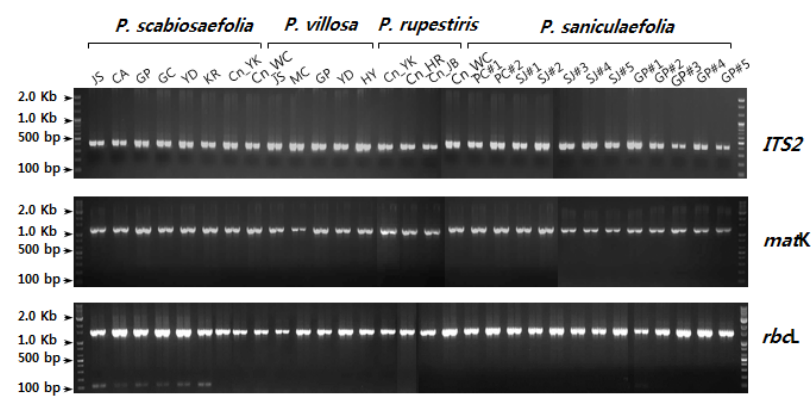

Fig. 1. PCR amplification of DNA barcode regions.

\section{DNA 바코드 염기서열 비교를 통한 종 감별}

\section{용 marker nucleotide 발굴}

\section{1) ITS2 부위 marker nucleotide 발굴}

패장 기원식물 및 관련 동속종의 환경적 요인에 의한 유전 적 변이 정도를 알아보기 위해 시료 개체별 염기의 삽입/결실 (indel)과 치환(substitution)을 비교 · 분석한 결과, 뚝갈, 마 타리, 돌마타리 3 종은 자생지 특이적인 변이가 관찰되지 않았 지만 금마타리의 경우는 지역 특이적 유전변이 뿐만 아니라 자생지별 염기서열 변이도 관찰되었다(Fig. 2). 이러한 변이 는 수집한 종내 개체 간에서 발생하는 것이 아니고 자생지별 로 특이성을 갖는 변이형태를 보였다. 본 연구는 패장의 정확 한 기원확립을 위해 종단위의 기원식물 판별에 이용 가능한 종별 특이 염기서열 발굴이 주목적으로 하고 있어 이러한 지 역별 변이나 자생지별 변이를 제외한 종 단위의 특이성을 갖 는 염기의 삽입/결실과 치환을 조사하여 정리 하였다. 

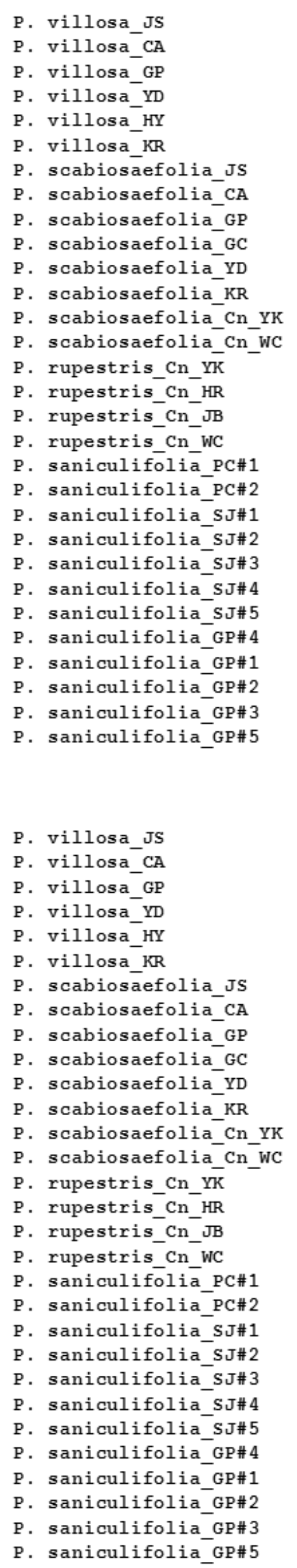

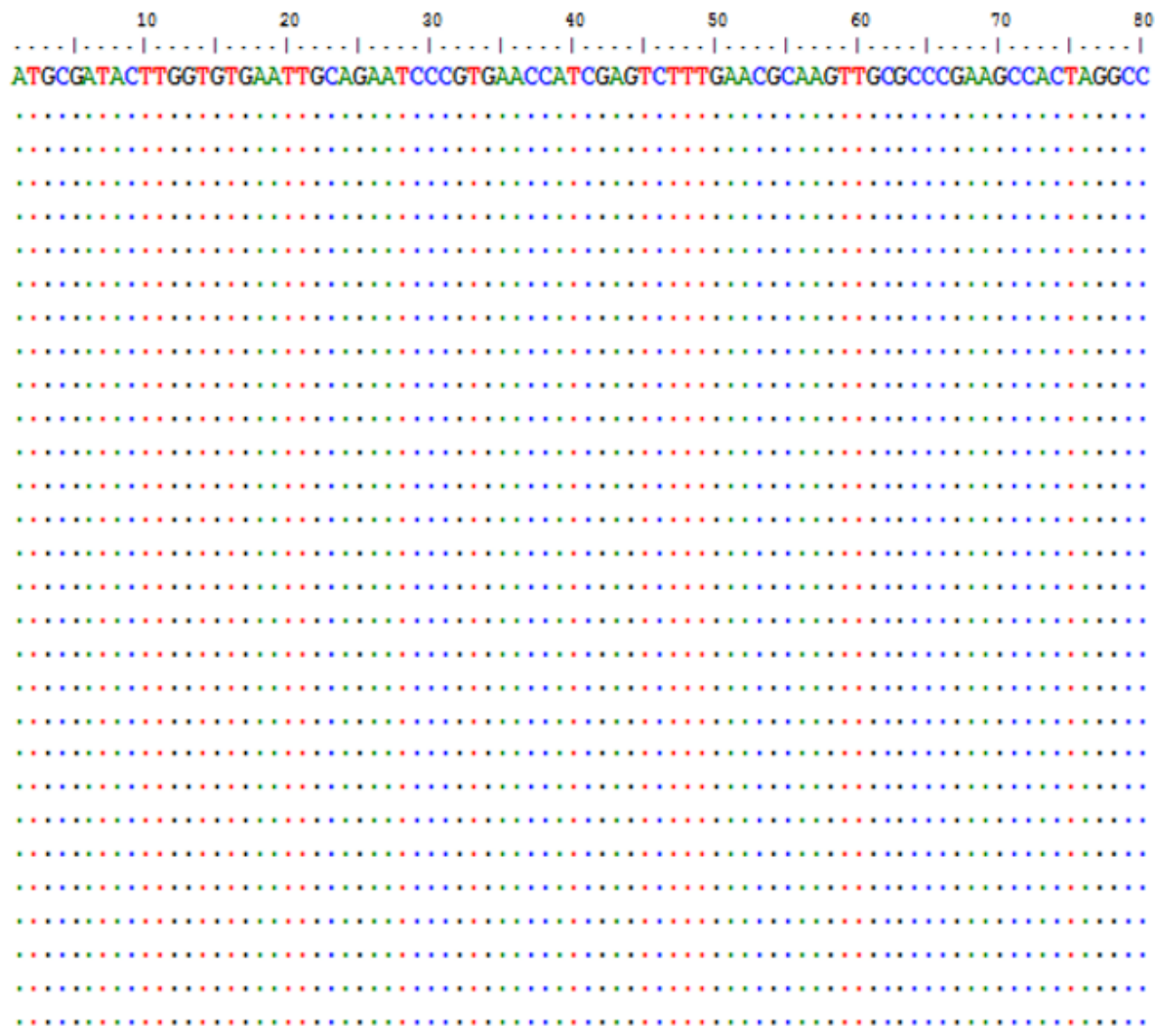

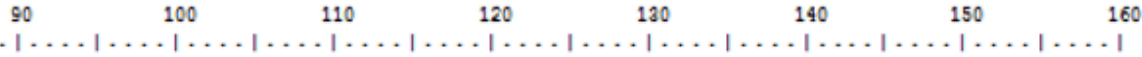 GAGGGCACGTCTGCCTGGGCGTCACGCATCGCGTCGCCCCCCC-AAACCCGC-TTCCAACGAAGTCGGCGTCGCGGGGGG}

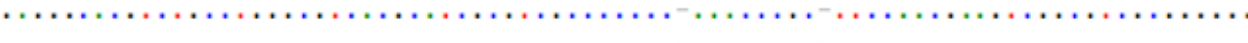

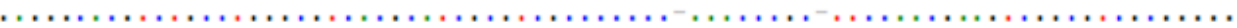

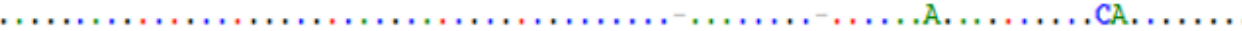

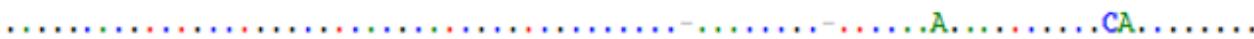

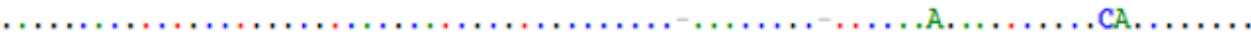

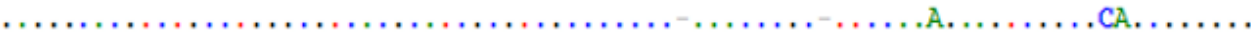

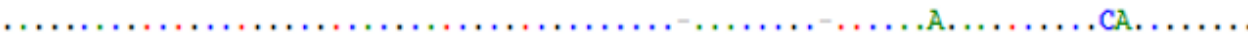

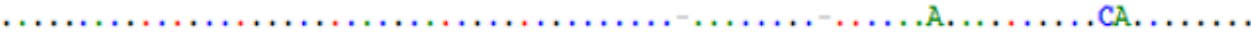

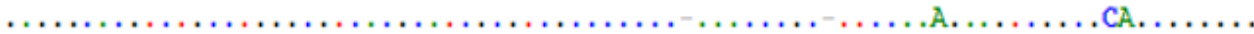

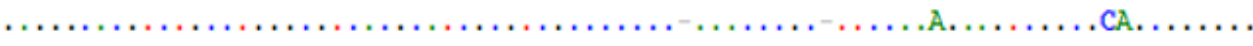

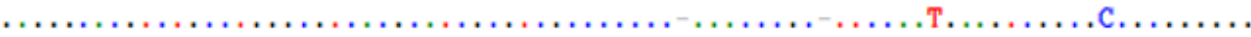

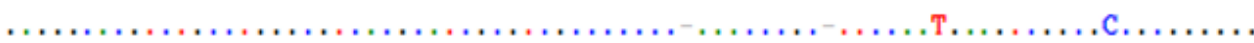

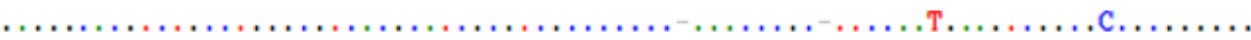

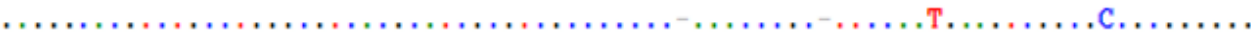

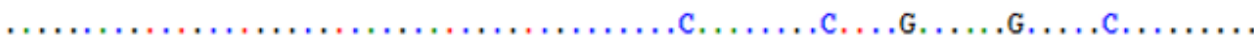

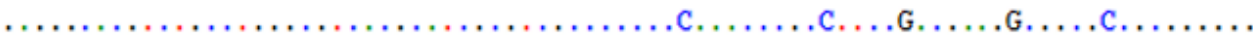

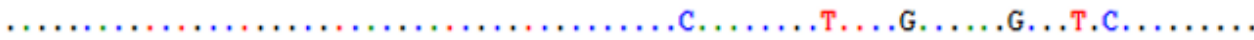

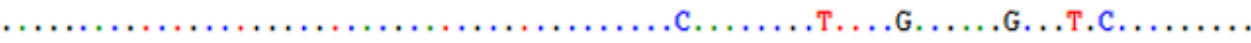

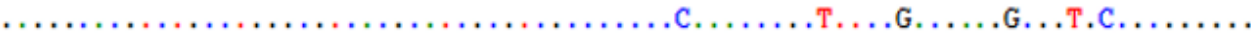

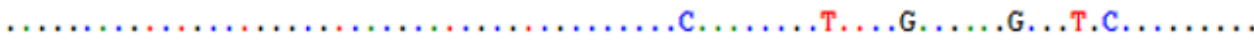

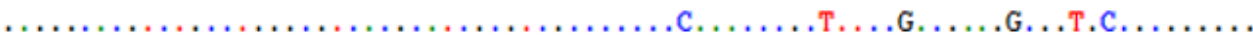

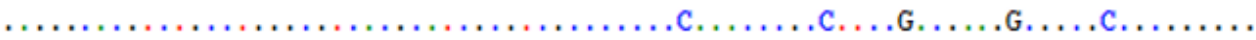

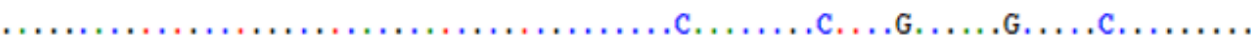

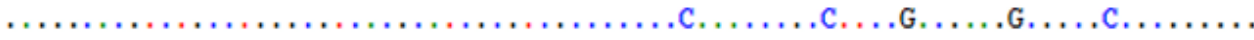

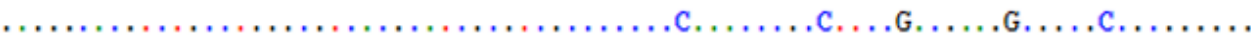

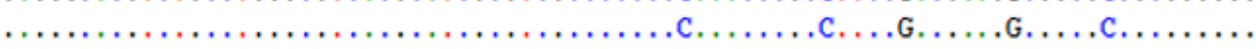

see the next page for the figure legend. 

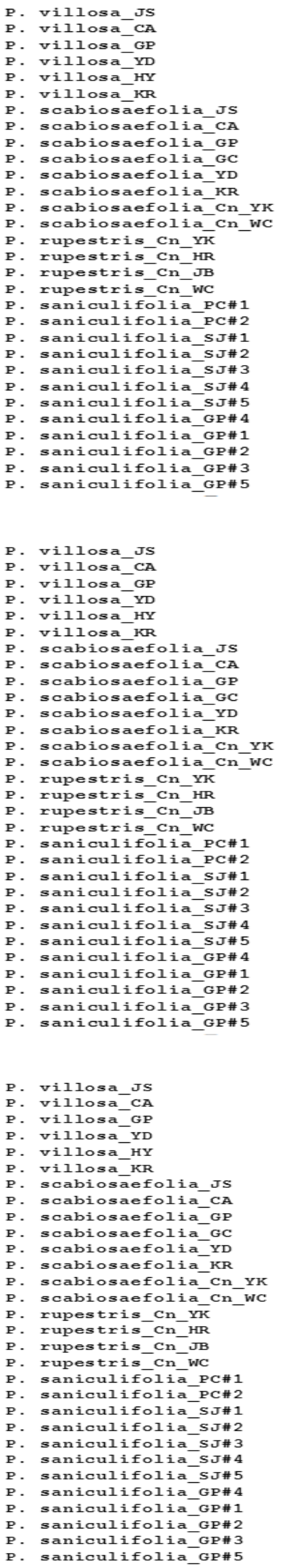

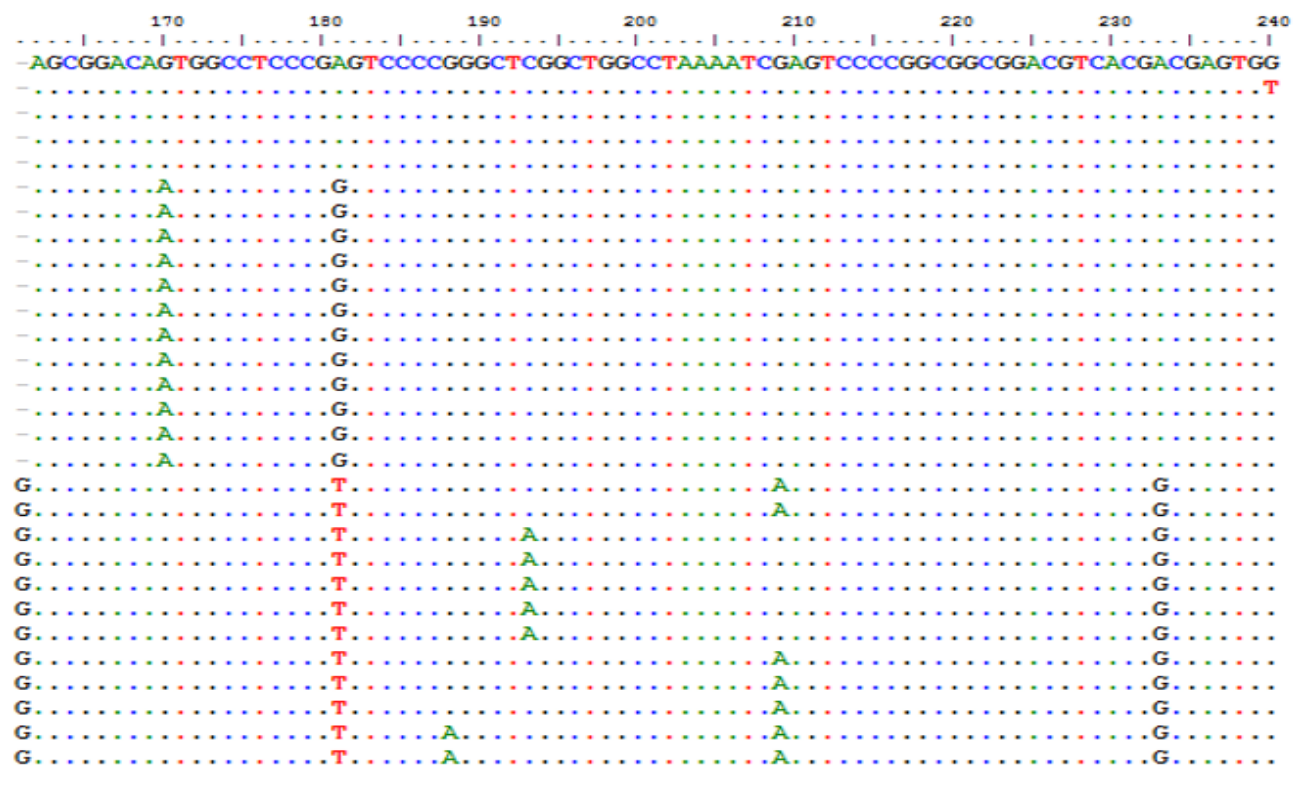

$250 \quad 260$

270

280

TGGTCGATACAGCCCTCTTATCGCGTCGTGCGTTTCCCCGTCGACCGGGCGACCAAGTGACCCTGACGCGTCGTCTTCCG

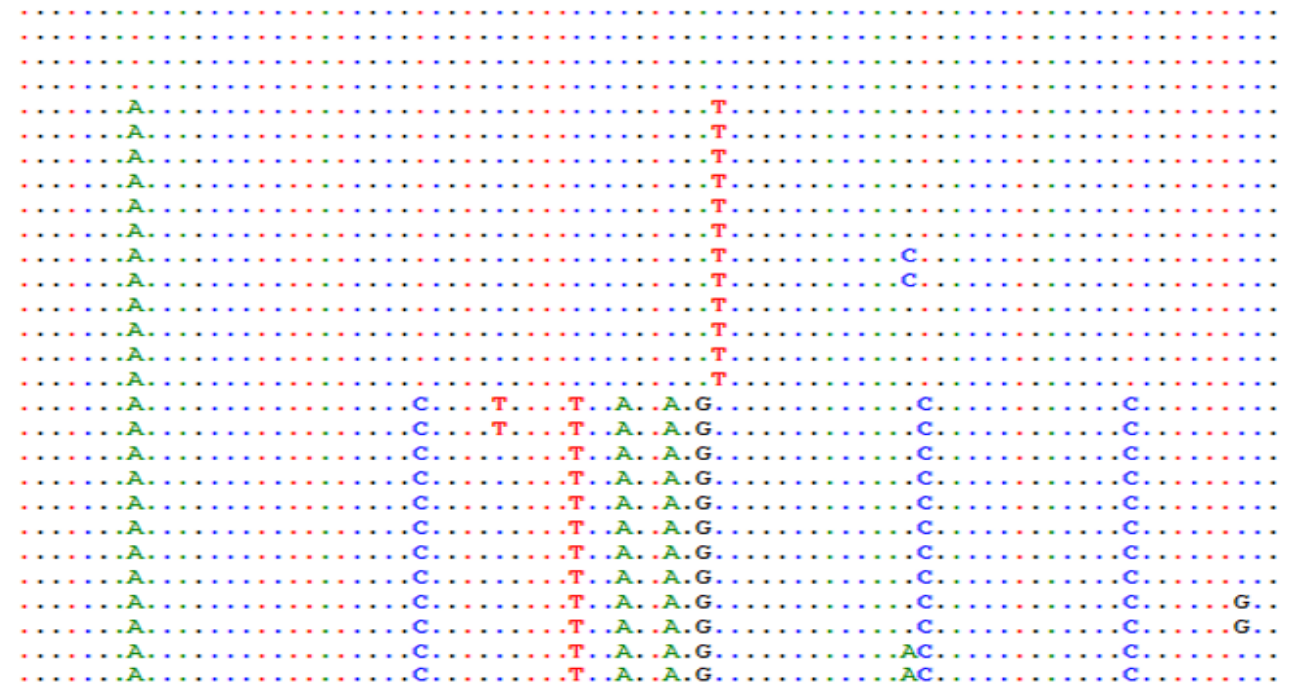

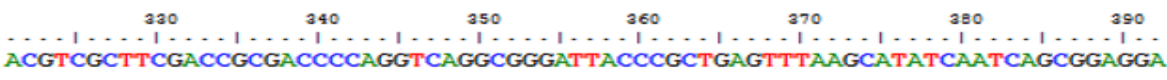

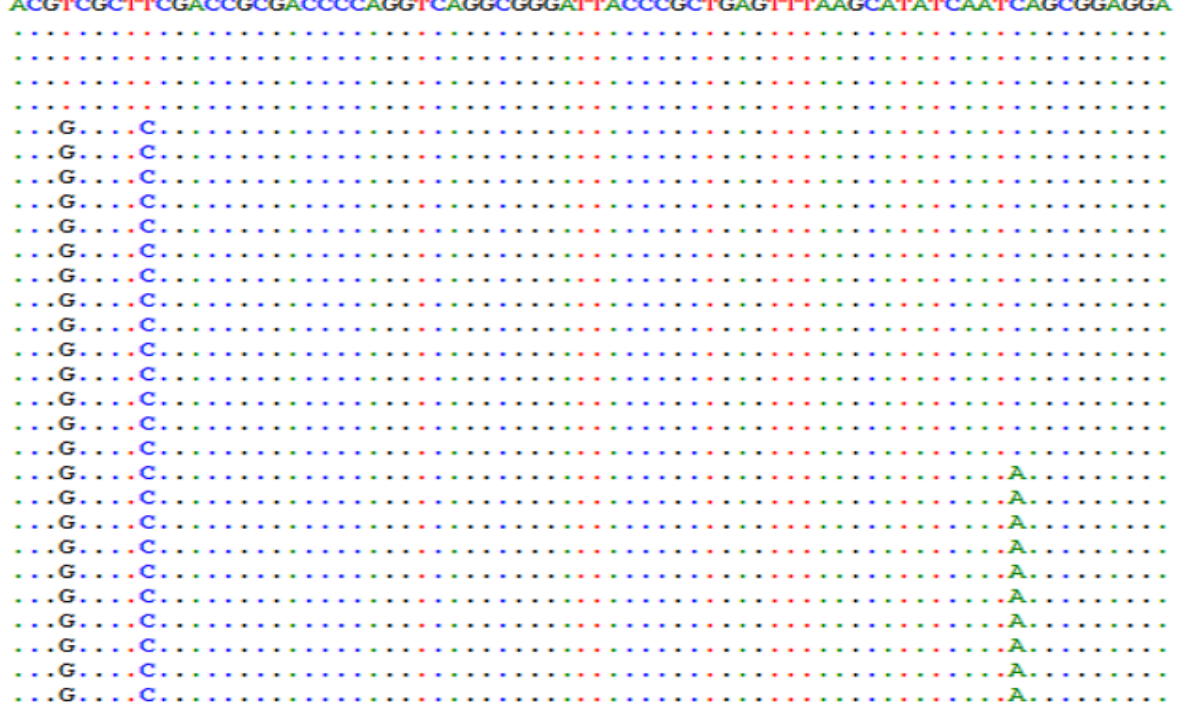

Fig. 2. Comparison of ITS2 region sequences for Patrinia species. Dots( $\cdot)$ indicate the identical sequences with Patrinia villosa and dashes(-) represents gaps introduced to maximize alignment. 
패장의 기원식물중 백화패장인 뚝갈의 ITS2 염기서열을 기 준으로 종간 염기서열 비교를 통해 확인된 종 특이적인 염기 의 삽입/결실 및 치환을 분석한 결과, 총 3 개의 삽입과 17 개 위치에서 19 개의 종 특이적 염기치환이 관찰되었다. 다른 종 과 구별이 가능한 종 특이적 염기치환은 뚝갈에서 5 개 위치 에서 확인되었으며, 마타리는 2 개의 위치, 돌마타리는 1 개의 위치, 그리고 금마타리의 경우는 11 개의 위치에서 염기치환이 일어났음을 확인할 수 있었다. 종내 변이를 제외한 종별로 공 통으로 확인된 종 특이적 삽입/결실 및 치환을 토대로 marker nucleotide를 분석한 결과, 삽입의 경우는 금마타리 에서 124 번 $\mathrm{C}, 133$ 번 $\mathrm{C} / \mathrm{T}$, 그리고 161 번 $\mathrm{G}$ 의 삽입이 확인
되었으며, 치환의 경우는 뚝갈이 5 개 위치의 염기치환으로 (151번 T↔C; 181번 $\mathrm{A} \leftrightarrow \mathrm{G} / \mathrm{T} ; 248$ 번 $\mathrm{T} \leftrightarrow \mathrm{A} ; 324$ 번 $\mathrm{T} \leftrightarrow \mathrm{G}$; 329 번 $\mathrm{A} \leftrightarrow \mathrm{G}$ ) 다른 3 종의 Patrinia속 식물과 종 단위 구별이 가능하였다. 마타리는 2 개 위치의 염기치환으로 $(140$ 번 $\mathrm{C} \leftrightarrow$ $\mathrm{A}$ 및 152 번 $\mathrm{C} \leftrightarrow \mathrm{A})$, 돌마타리는 1 개 위치의 염기치환으로 $(140$ 번 $\mathrm{C} / \mathrm{A} \leftrightarrow \mathrm{T})$, 그리고 금마타리는 11 개 위치의 염기치환 으로 (138번 $\mathrm{A} \leftrightarrow \mathrm{G} ; 145$ 번 $\mathrm{T} \leftrightarrow \mathrm{G} ; 181$ 번 $\mathrm{A} / \mathrm{G} \leftrightarrow \mathrm{T} ; 233$ 번 $\mathrm{A}$ $\leftrightarrow \mathrm{G} ; 266$ 번 $\mathrm{T} \leftrightarrow \mathrm{C} ; 276$ 번 $\mathrm{C} \leftrightarrow \mathrm{T} ; 279$ 번 및 282번 $\mathrm{C} \leftrightarrow \mathrm{A}$; 284 번 $\mathrm{A} \leftrightarrow \mathrm{G} ; 298$ 번 및 311 번 $\mathrm{T}-\mathrm{C}$ ) 각각의 종 판별이 가능한 SNP (Single Nucleotide Polymorphism) marker nucleotide 를 확인할 수 있었다(Fig. 2, Table 3).

Table 3. Summary of marker nucleotides from the comparison of the ITS2 sequences among 29 samples of 4 species for Patriniae Radix.

\begin{tabular}{|c|c|c|c|c|c|c|c|c|c|c|c|c|c|c|c|c|c|c|c|c|}
\hline Nucleotide Position & 124 & 133 & 138 & 140 & 145 & 151 & 152 & 161 & 181 & 233 & 248 & 266 & 276 & 279 & 282 & 284 & 298 & 311 & 324 & 329 \\
\hline P. villosa & - & - & $A$ & C & $\mathrm{T}$ & $T$ & $C$ & - & A & A & $T$ & $\mathrm{~T}$ & $C$ & $C$ & $C$ & $A$ & $\mathrm{~T}$ & $\mathrm{~T}$ & $T$ & $\mathrm{~T}$ \\
\hline P. scabiosaefolia & - & - & & $A$ & & C & $A$ & - & $G$ & & A & & & & & ........ & $\ldots$ & & G & C \\
\hline P. rupestris & - & - & & T & & C & & - & G & & A & & & & & . & & & $G$ & C \\
\hline P. saniculifolia & C & $\mathrm{C} / \mathrm{T}$ & G & & G & C & & G & $\mathrm{T}$ & G & A & C & $\mathrm{T}$ & A & A & G & C & C & G & C \\
\hline
\end{tabular}

Hyphens $(-)$ denote deletion of nucleotide for maximized alignment and dots $(\cdot)$ indicate sequence identity with $P$. villosa. Nuceotide positions indicate the aligned position starting from the 5' end of the ITS2 gene.

\section{2) makK 부위 marker nucleotide 발굴}

4 종 28 개 시료의 종내 개체간 삽입/결실과 치환을 확인한 결과, 종내 시료간 염기의 변이는 미미하게 관찰되었으며, ITS2에서 얻은 결과와 같이 금마타리 경북 성주 시료에서 지역 특이적인 염기치환이 관찰되었다 (data not shown). 금마타 리에서 관찰된 지역 특이적 염기 변이를 제외하고 종간 염기 서열 비교를 통해 종 판별에 활용 가능한 염기의 삽입/결실과 치환을 확인한 결과, 4 종에서 뚝갈을 기준으로 마타리, 돌마 타리 및 금마타리에서 1 개의 염기삽입과 21 개 위치에서 21 개의 종 특이적 염기치환을 확인할 수 있었다. 종내 변이를 제외한 종 특이적 삽입/결실 및 치환을 토대로 종 판별용 marker nucleotide를 분석한 결과, 뚝갈의 구별이 가능한 1,107 번
위치에서 $\mathrm{C}$ 의 결실이 확인되었다. 종 특이적 염기치환에 의한 종 판별용 marker nucleotide는 뚝갈은 2 개의 위치 $(1,106$ 번 $\mathrm{T} \leftrightarrow \mathrm{A}$ 및 1,111 번 $\mathrm{C} \leftrightarrow \mathrm{T})$, 마타리는 6 개 위치 $(198$ 번 $\mathrm{T} \leftrightarrow \mathrm{C}$; 255번 $\mathrm{G} \leftrightarrow \mathrm{A} ; 266$ 번 $\mathrm{C} \leftrightarrow \mathrm{A} ; 464$ 번 $\mathrm{C} \leftrightarrow \mathrm{T} ; 728$ 번 $\mathrm{A} \leftrightarrow \mathrm{C}$; 732 번 $\mathrm{G} \leftrightarrow \mathrm{A}$ ), 돌마타리는 2 개 위치 $(69$ 번 $\mathrm{G} \leftrightarrow \mathrm{A}$ 및 961 번 $\mathrm{C} \leftrightarrow \mathrm{T})$, 그리고 금마타리는 지역 특이적 염기 치환을 제외한 11 개 위치 (74번 $\mathrm{A} \leftrightarrow \mathrm{G} ; 185$ 번 $\mathrm{T} \leftrightarrow \mathrm{G} ; 244$ 번 $\mathrm{A} \leftrightarrow \mathrm{C}$; 336번 및 364번 $\mathrm{T} \leftrightarrow \mathrm{G} ; 420$ 번 및 513번 $\mathrm{A} \leftrightarrow \mathrm{G} ; 730$ 번 $\mathrm{A} \leftrightarrow \mathrm{C} ; 738$ 번 $\mathrm{C} \leftrightarrow \mathrm{A} ; 903$ 번 $\mathrm{T} \leftrightarrow \mathrm{C}$; 948번 $\mathrm{C} \leftrightarrow \mathrm{A})$ 에서 다른 3종의 Patrinia속 식물과 각각의 종 단위 구별이 가능한 SNP (Single Nucleotide Polymorphism) marker nucleotide를 확인할 수 있었다 (Table 4).

Table 4. Summary of marker nucleotides from the comparison of the makK sequences among 28 samples of 4 species for Patriniae Radix.

\begin{tabular}{|c|c|c|c|c|c|c|c|c|c|c|c|c|c|c|c|c|c|c|c|c|c|}
\hline Nucleotide Position & 69 & 74 & 185 & 198 & 244 & 255 & 266 & 336 & 364 & 420 & 464 & 513 & 728 & 730 & 732 & 738 & 903 & 948 & 961 & $\begin{array}{c}1,106 \\
- \\
1,107\end{array}$ & 1,111 \\
\hline P. villosa & G & A & $T$ & $T$ & $A$ & $\mathrm{G}$ & C & $\mathrm{T}$ & $T$ & $A$ & C & A & $A$ & $A$ & G & C & $\mathrm{T}$ & C & $C$ & $A-$ & C \\
\hline P. scabiosaefolia & & & & C & & $A$ & A & & 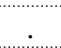 & . & T & & C & & A & & & 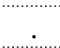 & & TC & T \\
\hline P. rupestris & A & & & $\cdots$ & & 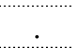 & . & $\cdots \cdots$ & . & . & & . & . & . & & . & . & . & T & TC & T \\
\hline P. saniculifolia & 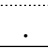 & G & G & & C & . & . & G & G & G & & G & . & C & & A & C & A & . & TC & T \\
\hline
\end{tabular}

Hyphens $(-)$ denote deletion of nucleotide for maximized alignment and dots $(\cdot)$ indicate sequence identity with $P$. villosa. Nuceotide positions indicate the aligned position starting from the $5^{\prime}$ end of the makk gene.

\section{3) rbd 부위 marker nucleotide 발굴}

4 종 28 개 시료의 종내 개체 간 삽입/결실과 치환을 확인한 결과, 종내 시료 간 염기의 변이는 미미하게 관찰되었으며, $\mathrm{ITS} 2$ 와 matK에서 얻은 결과에서와 마찬가지로 금마타리 경 북 성주 시료에서 하나의 지역 특이적인 염기치환이 관찰되었 다 (data not shown). 금마타리에서 관찰된 지역 특이적 염 기 변이를 제외하고 종간 염기서열 비교를 통해 종판별에 활 용 가능한 염기의 삽입/결실과 치환을 확인한 결과, 4 종에서 염기의 삽입/결실은 확인되지 않았으나 10 개 위치에서 12 개 의 종 특이 염기치환을 확인할 수 있었다. 종별 염기치환은 앞서 분석한 ITS2와 matK 유전자 부위에서와 같이 지역변이
를 보인 금마타리에서 6 개 위치가 관찰되어 가장 많은 변이 가 일어났음을 알 수 있었다. 금마타리를 제외한 나머지 3 종 에서는 뚝갈이 2 개 위치, 마타리가 3 개 위치, 그리고 돌마타 리에서 1 개 위치의 종 단위 구별이 가능한 염기 치환이 확인 되었다. 종내 변이를 제외한 종 특이적 삽입/결실 및 치환을 토대로 종 판별용 marker nucleotide를 분석한 결과, 종 특 이적 염기치환에 의한 종 판별용 marker nucleotide는 뚝갈 은 2 개의 위치 (509번 $\mathrm{A} \leftrightarrow \mathrm{T} / \mathrm{G}$ 및 970 번 $\mathrm{T} \leftrightarrow \mathrm{G}$ ), 마타리는 3 개위치 $(509$ 번 $\mathrm{A} / \mathrm{G} \leftrightarrow \mathrm{T} ; 534$ 번 $\mathrm{C} \leftrightarrow \mathrm{T} ; 1,207$ 번 $\mathrm{A} \leftrightarrow \mathrm{D})$, 돌 마타리는 1 개 위치 (510번 $\mathrm{CA} \leftrightarrow \mathrm{T})$, 그리고 금마타리는 지역 특이적 염기 치환을 제외한 6 개위치 $(152$ 번 $\mathrm{G} \leftrightarrow \mathrm{C} ; 153$ 번 C 
$\leftrightarrow \mathrm{A} ; 253$ 번 $\mathrm{A} \leftrightarrow \mathrm{G} ; 285$ 번 $\mathrm{C} \leftrightarrow \mathrm{G} ; 415$ 번 $\mathrm{G} \leftrightarrow \mathrm{A} ; 510$ 번 $\mathrm{C} / \mathrm{T}$ $\leftrightarrow \mathrm{A})$ 에서 다른 3 종의 Patrinia속 식물과 각각의 종 단위 구별이
가능한 SNP (Single Nucleotide Polymorphism) marker nucleotide를 확인할 수 있었다(Table 5).

Table 5. Summary of marker nucleotides from the comparison of the rbd sequences among 28 samples of 4 species for Patriniae Radix.

\begin{tabular}{|c|c|c|c|c|c|c|c|c|c|c|}
\hline Nucleotide Position & 152 & 153 & 253 & 285 & 415 & 509 & 510 & 534 & 970 & 1,207 \\
\hline$P \cdot$ villosa & $G$ & $\mathrm{C}$ & $A$ & $C$ & $G$ & $A$ & $C$ & $C$ & $\mathrm{~T}$ & $A$ \\
\hline P. scabiosaefolia & $\therefore$ &. & . & . & . & $\mathrm{T}$ & . & $\mathrm{T}$ & $\mathrm{G}$ & $\mathrm{G}$ \\
\hline P. rupestris & & 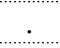 & & & . & G & $\mathrm{T}$ & & $\mathrm{G}$ & \\
\hline P. saniculifolia & C & A & G & G & A & G & A & & G & \\
\hline
\end{tabular}

Dots $(\cdot)$ indicate sequence identity with $P$. villosa. Nuceotide positions indicate the aligned position, starting from the 5' end of the rbd gene.

이상의 결과를 종합하면, 본 연구에서 확보한 패장 기원식 물과 관련 동속 종으로부터 확보한 DNA 바코드 부위인 $\mathrm{ITS} 2, \mathrm{matK}$, 그리고 $r b c \mathrm{~L}$ 유전자 염기서열을 기반으로 발굴 된 종 판별용 marker nucleotide는 한약재 패장의 종 감별 은 물론 생산단계나 종자 상태의 종 구분에 활용되어 패장의 기원식물이나 종자 동정은 물론 한약재의 진위를 종 단위에서 감별할 수 있는 객관적이고 유용한 분자마커로 활용 할 수 있 을 것으로 판단된다. 또한 금마타리의 경우는 다양한 지역에 서 추가 수집을 통해 DNA 바코드에 대한 지역 특이적 변이 와의 연관성을 추가 분석하여 향후 금마타리의 자생지 정보 관리나 원산지 판별 등에 활용 가능할 것으로 판단된다. 하지 만 이러한 지역 특이적 변이는 RAPD, AFLP 등의 유전자 지 문분석과 같은 방법으로 게놈 수준에서 보다 구체적인 연구가 필요할 것으로 사료된다.

\section{고 찰}

한약재의 정확한 감별은 한약의 약물동등성 확보와 표준화 에 있어서 가장 기본이 되면서 중요한 요소라고 할 수 있다. 한약재 감별법으로는 관능감별과 이화학 분석을 통한 감별, 그리고 유전자 분석을 통한 감별법이 일반적으로 사용되고 있 다. 한약재를 감별하는 가장 일반적 방법인 관능감별법은 약 재의 외부형태, 성상, 냄새 등에 의존하는 방법으로 다소 주 관적인 방법으로 감별자에 따라 그 결과가 차이를 보이는 단 점을 가지고 있다. 이화학적 분석을 통한 감별법은 품질관리 와 직접적으로 연계하여 활용할 수 있는 장점이 있지만 재배 기간, 재배지 또는 자생지의 환경 등 여러 가지 요소에 의해 정확한 기준을 설정하기가 어려운 단점을 지니고 있다 ${ }^{20,21)}$. 이러한 단점을 보완하기 위해 최근 유전자 분석을 통한 한약 재 감별법이 활발하게 연구되고 있다. 특히, DNA 바코드 분 석을 통한 한약재 종 감별 연구는 형태적 감별이 어려운 혼 - 오용 한약재 품목을 중심으로 종 단위의 정확한 감별법 개발이 국 - 내외에서 진행되고 있으며 ${ }^{22)}$, 국제생물바코드 컨 소시엄을 구성하여 전 세계 생물종에 대한 종 판별을 위한 체 계적인 연구를 진행하고 있는 실정이다 ${ }^{10-11)}$.

한약재 패장의 기원종인 마타리와 뚝갈은 두 종 모두 주로 항염증 효능을 나타내는 것으로 보고되었지만 항천식 효능 종 비교 연구에서는 뚝갈이 마타리보다 효능이 우수하고 그 작용 기작도 차이를 보일뿐만 아니라 ${ }^{4)}$ 마타리, 뚝갈, 돌마타리 및 금마타리의 구성성분 비교연구에서 뚝갈이 다른 Patrinia속과 는 성분구성의 차이를 보인다는 연구결과 ${ }^{23)}$ 를 바탕으로 종 감 별 연구를 통해 이들의 정확한 구별법 개발을 수행하였다. 따 라서, 황화패장과 백화패장을 구별하고 혼 · 오용될 가능성이
있는 같은 속의 식물인 돌마타리와 금마타리를 정확하게 감별 하기 위해 rDNA-ITS, ITS2, matK, $r b c \mathrm{~L}$ 바코드 부위를 분석하여 이들의 종 감별에 활용 가능한 marker nucleotide 를 발굴하고자 하였다. 각 $\mathrm{DNA}$ 바코드 부위의 증폭한 결과 로부터 $\mathrm{rDNA}$-ITS 부위는 동일한 크기의 단일 $\mathrm{DNA}$ 절편이 증폭되지 않고 크기가 다른 다수의 절편이 증폭되어 패장 감 별을 위한 DNA 바코드로는 적합하지 않았으며(data not shown), 나머지 3 개 부위는 단일 $\mathrm{DNA}$ 절편이 증폭되어 패 장 감별에 활용 가능한 유전자 부위임을 확인하였다. 단일 절 편이 증폭된 3 개 유전자 부위 염기서열의 종 특이적인 삽입/ 결실 및 치환을 확인한 결과에서 감별하고자 하는 Patrinia속 4종의 정확한 구별이 가능한 marker nucleotide를 확인할 수 있었으며, 바코드별로는 ITS2와 matK가 22개로 많았고 $r b c \mathrm{~L}$ 은 12 개로 적은 편이었다. 이러한 결과는 $r b c \mathrm{~L}$ 유전자 부위의 변이의 속도가 느려 종 단위 이하의 동정이나 계통학 적 유연관계 분석에 적합하지 못하다는 이전의 연구결과와 일 치하는 경향을 Patrinia속에서도 확인 할 수 있었다 ${ }^{24)}$. 4 종에 대한 변이의 정도를 종별로 나누어 보면 금마타리가 31 개 위 치로 가장 많았으며 마타리 11 개 위치, 뚝갈 10 개 위치, 그 리고 돌마타리 4 개 위치의 순으로 나타났다. 따라서 본 연구 에서 분석한 3 개 DNA 바코드 부위를 이용하여 패장의 종 감 별을 위해서는 바코드 부위 3 개 전체 염기서열을 분석하지 않고 각각의 바코드 부위 분석을 통해서 종 단위 감별이 가능 하며, 보다 정확한 감별이 요구될 경우에는 두 개 이상의 바 코드 부위 염기서열 분석을 통해 감별의 신뢰성을 높일 수 있 을 것으로 판단된다. 각 $\mathrm{DNA}$ 바코드 부위 유전자 염기서열 을 종내 개체 또는 지역별 비교를 통해 확인한 결과, 마타리, 뚝갈, 그리고 돌마타리에서는 특이성을 가지는 염기서열이 확 인되지 않은 반면에 금마타리의 경우에는 경기도, 강원도, 경 상북도에서 수집한 시료에서 지역별로 공통된 특이성을 갖는 염기서열의 치환이 확인되었을 뿐만 아니라 경기도 시료의 경 우에는 자생지별 특이성을 갖는 염기서열의 치환도 확인되었 다. 이러한 결과는 같은 Patrinia속 식물이지만 금마타리는 서식환경이 해발 $600 \mathrm{~m}$ 이상의 고지대에서 자생하고 있는 생 육특성으로 인하여 자생지별로 격리되어 서식하고 있어 이러 한 환경적 요인은 자생지별 독립적인 유전변이에 의해 나타는 현상이거나 금마타리가 Patrinia속 식물중에서 다른 종과는 달리 종 분화가 진행되고 있는 식물이기 때문에 나타나는 현 상으로 판단된다. 금마타리의 이러한 자생지 및 지역별 염기 서열 변이는 비슷한 서식환경에서 자생하는 식물 종의 지역별 수집을 통해 정확한 원인을 추가 분석하여 검증하는 것은 향 후 유전자 분석을 통한 한약재의 정확한 종 감별뿐만 아니라 원산지 판별 등에 활용 가능한 중요한 정보를 제공할 수 있을 
것으로 기대된다. 하지만 DNA 바코드 기법을 이용하여 실제 검사기관에서 유통되는 한약재 감별과정에서 정확한 종의 판 별과 유사종의 혼입여부를 판별하기 위해서는 분자생물학적 지식이 요구되고 분석량이 많아 보다 경제적인 감별법 개발을 위해서는 종별 특이 DNA 바코드 염기서열을 이용하여 직접 적인 판별이 가능한 SCAR 마커나 나아가 multiplex SCAR 마커의 개발을 통해 그 활용도와 적용성을 제고할 필요가 있 을 것으로 사료된다.

본 연구에서는 패장의 정확하고 객관적인 감별법 개발을 위해 다양한 DNA 바코드 부위 염기서열을 분석하고 ITS2, $m a t \mathrm{~K}, r b c \mathrm{~L}$ 유전자 부위 염기서열의 종별 특이성을 바탕으 로 marker nucleotide를 발굴하여 패장의 약전 수재 종인 마타리, 뚝갈과 혼·오용 가능성이 있는 돌마타리와 금마타리 를 종단위로 감별할 수 있는 분자생물학적인 감별법을 개발하 였다. 이러한 결과는 패장을 신속하고 명확하게 감별할 수 있 는 분자 마커로 활용하여 한약의 기원확립과 약물동등성 확보 를 위한 표준화 기법으로 충분한 가치가 있을 뿐만 아니라 한 약재 생산단계나 유통현장에서 대용품이나 위품의 생산 - 유통 을 방지할 수 있는 기술로 활용되어 한약에 대한 신뢰회복에 이바지 할 것으로 기대된다.

\section{결 론}

본 연구는 한약재 패장을 약재 상태에서 종단위로 정확하 게 구별하고 유사한약재로 사용될 가능성이 있는 같은 속 식 물인 돌마타리와 금마타리의 혼 - 오용을 막기 위한 효과적 감 별법 개발을 위하여 분자생물학적인 기법의 일환으로 ITS2, $m a t \mathrm{~K}$ 및 $r b c \mathrm{~L} \mathrm{DNA}$ 바코드 부위 유전자 염기서열 분석을 통해 다음과 같은 결과를 얻었다.

1. 4종 Patrinia속 식물의 DNA 바코드 염기서열 분석을 통해 ITS2와 matK 유전자는 삽입/결실이 관찰되어 각 각 389-392bp와 1,261-1,262bp로 구성되어 있었고 $r b c \mathrm{~L}$ 유전자는 삽입/결실 없이 $1,497 \mathrm{bp}$ 로 구성되어 있었으며, 이들 바코드 부위는 각각 $22,22,12$ 개의 종 감별이 가능한 marker nucleotide를 포함하고 있었다.

2. ITS2, matK 및 $r b c L$ 세개의 유전자 염기서열 분석을 통해 각 DNA 바코드 부위의 marker nucleotide 수, 염기의 삽입/결실 및 치환 수, 활용성 등을 비교한 결 과, matK와 $r b c \mathrm{~L}$ 유전자 부위에 비해 ITS2 유전자 부위가 길이가 짧고 4 종을 모두 감별 할 수 있어 패장 의 감별에 가장 유용한 DNA 바코드로 이용할 수 있을 것으로 판단된다.

\section{감사의 글}

본 연구는 한국한의학연구원 '한의본초활용기반구축사업 (K12020)'과 한약자원 국내 생산 기반기술 개발과제(K14417) 의 지원에 의해 수행되었으며, 기원식물 분류·동정에 도움을 주신 분류·동정 자문위원님들께 감사드립니다.

\section{References}

1. Herbology Editorial Committee of Korean Medicine School. Korean Herbology(Boncho-hak). Seoul : Younglimsa. 2010 : 255-6.

2. Chang WH, Park SW, Chang SY, Yook CS. The studies on chemical components of Valerianaceae. Bull K H Pharma Sci. $2001 ; 29: 1-9$.

3. Korea Institute of Oriental Medicine. Defining Dictionary for Medicinal Herbs [Korean], Retrieved Oct. 06, 2014, from http://boncho.kiom.re.kr/codex/.

4. Cha JT, Lee JC, Lee YC. Comparative study on anti-asthmatic activities of Patrinia scabiosaefolia Fischer ex link and Patrinia villosa Jussieu in a mouse model of asthma. Kor J Herboogy. 2012 ; 27(3) : 75-82.

5. Guo YL, Ge S. Molecular phylogeny of Oryzeae (Poaceae) based on DNA sequences from chloroplast, mitochondrial, and nuclear genomes. Am J Bot. 2005 ; 92(9) : $1548-58$.

6. Cabrera LI, Salazar GA, Chase MW, Mayo SJ, Bogner J, Davila P. Phylogenetic relationships of Aroids and Duckweeds (Araceae) inferred from coding and noncoding plastid DNA. Am J Bot. 2008 ; 95(9) ; 1153-65.

7. Foster PG, Bergo ES, Bourke BP, Oliveira TM, Nagaki SS, Snatana DC, Sallum MA. Phylogenetic analysis and DNA-based species confirmation in Anopheles (Nyssorhynchus). PLoS ONE. 2013 ; 8(2) : e54063

8. Kim YD, Park CW, Sun BY, Kim KJ, Lee EJ, Kim $\mathrm{SH}$. ITS sequence variations in common ragweed and giant ragweed. Korean J Plant Taxon. 2005 ; 35(4) : 273-85.

9. Barcode of Life. Identifying species with DNA barcoding Retrieved Oct. 06, 2014, from http://www. barcodeoflife.org.

10. BOLDsystem. Databases and Identification Request Retrieved Oct. 06, 2014, from http://www.boldsystems.org.

11. Lee YM, Moon BC, Ji Y, Kim WJ, Kim HK. Molecular Authentication of Pinelliae Tuber from its adulterants by the analysis of DNA barcodes, matK and rbcL genes. Kor J Herboogy. 2013 ; 28(3) : 75-84.

12. Song IG, An BR, Seo BI, Park SJ. Molecular marker to identify and origin of Cnidii Rhizoma from Korea and China. Kor J Herbology. 2009 ; 24(4) : 1-8.

13. Moon BC, Choo BK, Ji Y, Yoon T, Lee AY, Cheon MS, Kim BB, Kim HK. Molecular authentication and phylogenetic relationship of Bupleurum species by the rDNA-ITS sequences. Kor J Herbology. 2009 ; 24(3) : 59-68.

14. Kim JS, Jang HW, Kim JS, Kim JH, Kim JH. Molecular identification of Schisandra chinensis and 
its allied species using multiplex PCR based on SNPs. Genes Genomics. 2012 ; 34 : 283-90.

15. Hall TA. BioEdit: an user-friendly biological sequence alignment editor and analysis program for Windows 95/98/NT. Nucl Acid S. 1999 ; 41 : 95-8.

16. White TJ, Bruns T, Lee S, Taylor J. Amplification and direct sequencing of fungal ribosomal RNA genes or phylogenetics. In: PCR Protocols: a guide to methods and amplifications. New York : Academic Press. 1990 : 315-22.

17. Kato H, Oginuma K, Gu Z, Hammel B, Tobe H. Phylogenetic relationships of Betulaceae based on matK sequences with particular reference at the positions of Ostryopsis. Acta phytotax Geobot. 1998 ; 49(2) : 89-97.

18. Chen S, Yao H, Han J, Liu C, Song J, Shi L, Zhu Y, Ma X, Gao T, Pang X, Luo K, Li Y, Li X, Jia $\mathrm{X}$, Lin $\mathrm{T}$, Leon $\mathrm{C}$. Validation of the ITS2 region as a novel DNA barcode for identifying medicinal plant species. PLos ONE. 2010 ; 5(1) : e8613.

19. Mansion G, Rosenbaum G, Schoenenberger N, Bacchetta G, Rosselló JA, Conti E. Phylogenetic analysis informed by geological history supports multiple, sequential invasions of the Mediterranean Basin by the angiosperm family Araceae. Syst Biol. 2008 ; 57(2) : 269-85.

20. Joshi K, Chavan P, Warude D, Patwardhan B. Molecular markers in herbal drug technology. Curr Sci. 2004 ; 87(2) : 159-65.

21. Choo BK, Moon BC, Ji Y, Kim BB, Choi G, Yoon T, Kim HK. Development of SCAR markers for the discrimination of three species of medicinal plants, Angelica decursiva (Peucedanum decursivum), Peucedanum praeruptorum and Anthricus sylvestris, based on the internal transcribed spacer (ITS) sequence and random amplified polymorphic DNA (RAPD). Biol Pharm Bull. 2009 ; 32(1) : 24-30.

22. Shucher NJ, Carles MC. Genome-based approaches to the authentication of medicinal plants. Planta Med. 2008 ; 74(6) : 603-23.

23. Kim JS, Kang SS. Chemical constituents of plants from the genus Patrinia. Nat Prod Sci. 2013 ; 19(2) : 77-119.

24. Olmstead RG, Reeves PA. Evidence for the polyphyly of the Scropulariaceae based on choloroplast rbcL and $n d h F$ sequences. Ann Missouri Bot Gard. 1995 ; 82(2) : 176-93. 